\title{
Green Synthesis and Characterization of Silver Nanoparticles using Crude Extract of Crotalaria burhia
}

\author{
Khalil Ahmad', Raeesa Noor', Muhammad Younus ${ }^{2}$, Muhammad Akram Choohan', Ume Habiba ${ }^{1, *}$, Hafiz \\ Muhammad Asif', Abdul Wadood Chishti', Sohaib Saifullah ${ }^{1}$ \\ 1 University College of Conventional Medicine, Faculty of Health and Allied Health Sciences, The Islamia \\ University of Bahawalpur, Bahawalpur, Pakistan. \\ ${ }^{2}$ Department of pharmacognosy, Faculty of Pharmacy, The Islamia University of Bahawalpur, Bahawalpur, \\ Pakistan.
}

\begin{abstract}
Authors' Contributions
1 Conception \& Study design, Data Analysis and/or Interpretation.

2 \& 4 Data Collection \& Processing, Drafting of Manuscript.

3 Critical Review.

5 Drafting of Manuscript, Critical Review.

6 Data Analysis and/or Interpretation, Critical

Review.

7 Data Collection \& Processing.

8 Data Analysis and/or Interpretation.
\end{abstract}

\section{Acknowledgement}

\section{Article info.}

Received: December 06, 2020

Accepted: January 25, 2021

Funding Source: Nil

Conflict of Interest: Nil

Cite this article: Ahmad $K$, Noor $R$, Younus M. Choohan MA, Habiba U, Asif HM, Chishti $A W$, Saifullah S. Green Synthesis and Characterization of Silver Nanoparticles using Crude Extract of Crotalaria burhia. RADS J Pharm Pharm Sci. 2020; 8(4):209-215.

*Address of Correspondence Author: um-e-habiba2011@hotmail.com

\begin{abstract}
A B S T R A C T
Background: Appearance of antibiotic resistance has raised the demand to find alternative therapies and modified drug delivery system of medicinal plants to treat bacterial infections.
\end{abstract}

Objective: The aim of this study is the green synthesis and characterization of silver nanoparticles by using crude extract of Crotalaria burhia and to evaluate their antibacterial potential.

Methods: The roots and stems of plant were used to prepare the crude extract. The phytochemical analysis of different compounds in extract was performed. $1 \mathrm{mM} \mathrm{AgNO}_{3}$ and different concentrations of plant extract were used for the green synthesis of silver nanoparticles. The particles size and zeta potential were measured by zeta sizer while surface morphology of silver nanoparticles was observed with Scanning Electron Microscope (SEM). The antibacterial activity of silver nanoparticles was performed by 96 well microdilution plate method.

Results: The particle size and zeta potential of optimized formulation was 92 $\mathrm{nm}$ and $-24.8 \mathrm{mV}$. The SEM analysis showed that silver nanoparticles are irregular and spherical shape. The antibacterial activity showed that MIC value of silver nanoparticles was lower for $E$. coli than $S$. aureus.

Conclusion: Silver nanoparticles possess potent bactericidal activity against $E$. coli and moderate activity against $S$. aureus. It had been concluded that these nanoparticles can be used against multi-drug resistant bacterial infections.

Keywords: Crotalaria burhia; Silver nanoparticles; Antibiotics resistance; Antibacterial.

\section{INTRODUCTION}

Medicinal plants and their potential chemical constituents play a major role in the well-being of poor communities around the world [1]. Phytomedicine has a wide range of therapeutic benefits, therefore they are considered appropriate in the treatment of diseases and has a central place in healthcare around the world [2]. Phytomedicine has lesser side effects than synthetic medicines and is of considerable significance in the treatment of transmissible diseases [3].

Crotalaria burhia is a desert plant. The Genus Crotalaria burhia which belongs to family Fabaceae is 
commonly present in dry places of the west Afghanistan, India as well as Pakistan [4]. The novel drug delivery system is an advanced and modern system which is designed for the optimum delivery of drugs. Recent advances in drug pharmacokinetics \& pharmacodynamics has led the giant pharmaceutical manufacturer to design different drug delivery system of conventional drugs, because synthesis of new drug molecule is expensive as compared to development of new drug delivery system [5]. In the 21st century, the use of small sized nanoparticles is a best approach for the delivery of active drug to cure different diseases. For this reason, the pharmacists, drug delivery scientists and researchers shift their focus on developing a novel drug delivery system for herbal medicines [6].

Silver nanoparticles (Ag Nps) are silver crystals, with a common particle size of $1 \mathrm{~nm}$ to $100 \mathrm{~nm}$. They consist of a high percentage of silver oxide because of their large surface to bulk silver atoms [7]. The primary requirement of $\mathrm{Ag}$ NPs green synthesis is the solution of silver metal ion and a reduction biological agent. In most cases, reducing agents or other constituents in the cells act as a stabilizing and capping agent and there is no need to add external capping stabilizing agents [8]. The usage of nanotechnology in herbal drugs has demonstrated numerous benefits for herbal medicines which are improved solubility, bioavailability and improved pharmacological activity. This produces less toxicity and prevents chemical and physical degradation of the crude drug [9] So, the green synthesis of silver nanoparticles can be an effective and safe way for eradication of multidrug resistant bacterial infections [10] therefore the aim of this study is to green synthesize and characterize silver nanoparticles by using Crotalaria burhia plant extract and to evaluate antibacterial potential of silver nanoparticles.

\section{MATERIALS AND METHODS}

\section{Collection of Plant}

Crotalaria burhia plant was collected from the Cholistan desert of Bahawalpur, Pakistan. The plant was verified by Prof. Dr. Ghazala H. Rizwani (Director Research, Hamdard University, Karachi, Pakistan). The dried sample of plant was stored in pharmacognosy research list with reference number A138.

\section{Preparation of Crude Extract}

Stem and roots of Crotalaria burhia plant were taken and shade-dried. The whole dried-plant was ground to fine powder by using grinder. Powdered material of plant was added into hydroethanolic (30/70 v/v) solvent for 3 days. The plant and solvent mixture was agitated daily to dissolve phytochemicals in solvent. After 3 days, the mixture was filtered on muslin cloth and Whatman filter paper. The solvent of filtrate was evaporated on rotary evaporator at $35^{\circ} \mathrm{C}$ and a thick gummy extract was obtained which was stored at $4^{\circ} \mathrm{C}$ in refrigerator [11].

\section{Green Synthesis of Silver Nanoparticles}

$40 \mathrm{ml}$ of $1 \mathrm{Mm}$ silver nitrate solution was taken and different concentrations of plant extract were added in it (Table 1). The reaction mixture was placed on magnetic stirrer for 6 hours with constant magnetic stirring at $400 \mathrm{rpm}$. The color of solution changed from orange to dark brown which indicated the synthesis of silver nanoparticles. The synthesis of silver nanoparticles was further confirmed with UV analysis at 400 to $700 \mathrm{~nm}$ wavelength. The liquid sample of silver nanoparticles was centrifuged at $12000 \mathrm{rpm}$ for 30 minutes. The pellets of Ag NPs were washed with water and lyophilized on lyophillizer. After lyophilization, the solid sample of nanoparticles was stored at $4^{\circ} \mathrm{C}$ for further characterization and antibacterial assay [11].

Table 1. Different Concentrations of Plant Extract. Green Synthesis of Silver Nanoparticles.

\begin{tabular}{|c|c|c|}
\hline $\begin{array}{c}\text { Formulation } \\
\text { No. }\end{array}$ & $\begin{array}{c}\text { Silver nitrate } \\
\mathbf{1 m M} \text { (m) }\end{array}$ & $\begin{array}{c}\text { Plant extract } \\
\text { (mg/ml) }\end{array}$ \\
\hline 1. & 40 & 5 \\
\hline 2. & 40 & 10 \\
\hline 3. & 40 & 15 \\
\hline 4. & 40 & 20 \\
\hline 5. & 40 & 25 \\
\hline
\end{tabular}

The silver nano particles were powdered and characterized by visual observation, UV visible spectroscopy, FTIR spectroscopy, zeta sizer and Scanning Electron Microscopy (SEM). UV visible spectrophotometry was performed to analyze the reduction of silver into silver ion which refers to completion of reaction. FTIR spectroscopy (Bruker 
Tensor 27 series) at wavelength range of 500 to 4000 $\mathrm{cm}^{-1}$. The transmittance spectra were analyzed on OPUS software running on Windows PC. The zeta sizer (Malvern instruments, UK) was used to analyze the size and zeta potential of silver nanoparticles. SEM analysis was performed at Central Research Lab, Lahore College for Women University (LCWU), Lahore. In SEM analysis, the surface morphology and shape of silver nanoparticles was analyzed. highresolution images were captured at $25 \mathrm{kV}$ [12].

\section{Anti-Oxidant Activity}

\section{2, 2-Diphenyl-1-Picrylhydrazyl (DPPH) Method}

$10 \mu \mathrm{l}$ drug solution and $90 \mu \mathrm{l}$ of $100 \mu \mathrm{M}$ methanolic solution of DPPH was taken in 96 well microplate (Figure 1) and incubated for half hour at $37^{\circ} \mathrm{C}$. After incubating the samples were analyzed at $517 \mathrm{~nm}$ wavelength with the help of microplate reader. The absorbance value was measured thrice and compared with the standard [13].

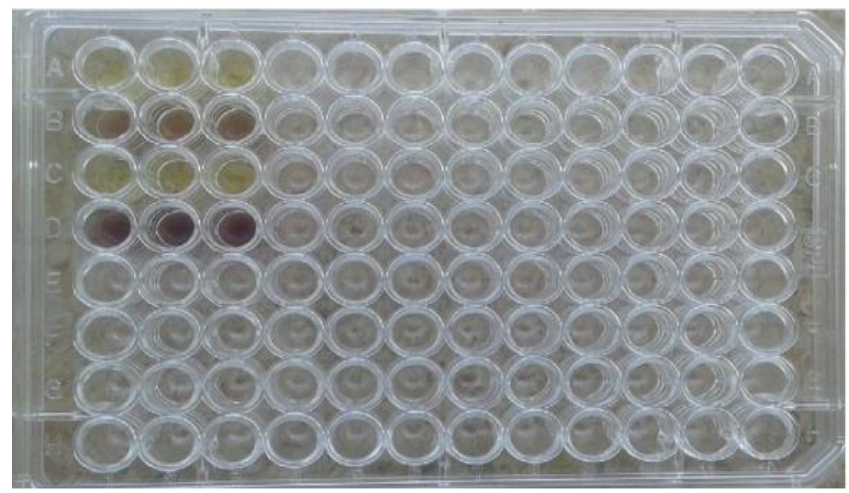

Figure 1. DPPH assay by 96 microwell plates method.

$\mathrm{IC}^{50}$ value was measured by Ez-fit-5 Perrellea Sientic Inc. USA. The final inhibitory percentage was calculated by following mathematical equation

Scavenging potential $(\%)=$ Abs. of Control - Abs. of test / Abs. of control $\times 100$

Absorbance of test $=$ Radical effect of test compound

Abs. of control = Total radical effect without any inhibitor.

\section{Antibacterial Activity}

The antibacterial activity of silver nanoparticles was performed against two bacterial strains E. coli (Gram negative) and $S$. aureus (Gram positive). The 96 well microdilution plate method with broth medium was used to determine the minimum inhibitory concentration (MIC). The bacterial strains $\left(5 \times 10^{5}\right.$ $\mathrm{CFU} / \mathrm{ml}$ concentration) were exposed with different dilutions (different concentrations) of silver nanoparticles, plant extract and silver nitrate. The 96 well plates were incubated at $37^{\circ} \mathrm{C}$ for 24 hours in aerobic condition. The concentration which restrict the visual growth of bacteria was considered as MIC. The standard for antibacterial activity was Ciprofloxacin [14].

\section{RESULTS}

\section{Phytochemical Analysis}

On phytochemical analysis of hydro-alcoholic extract of plant high amount of carbohydrates was found. The mild amount of saponins, phenols, tannins, proteins and quinines was found in extract. The mild quantity of fats and oils and high quantity of flavonoids was also found in Crotalaria burhia extract. Mild to moderate quantity of alkaloids and glycosides was also present. While high quantity of terpenes was present in this crude extract (Table 2).

Table 2. Phytochemical Analysis of Crotalaria burhia.

\begin{tabular}{|c|c|c|}
\hline Sr No. & $\begin{array}{c}\text { Chemical } \\
\text { compound }\end{array}$ & $\begin{array}{c}\text { Crotalaria burhia } \\
\text { extract }\end{array}$ \\
\hline 1 & Tannins & + \\
\hline 2 & Alkaloids & ++ \\
\hline 3 & Glycosides & ++ \\
\hline 4 & Saponins & ++ \\
\hline 5 & Terpenes & ++ \\
\hline 6 & Fats and oils & + \\
\hline 7 & Proteins & +++ \\
\hline 8 & Phenols & + \\
\hline 9 & Carbohydrates & +++ \\
\hline 10 & \multicolumn{2}{|c|}{ Quinones } \\
\hline 11 & \multicolumn{2}{|c|}{ Flavonoids } \\
\hline $\begin{array}{l}\text { indicate } \\
\text { indicate high amount of compounds in the crude } \\
\text { extract. While, - indicate the absence of compound in } \\
\text { the crude extract. }\end{array}$
\end{tabular}




\section{Visual Observation}

The concentration of silver nitrate was kept constant and different concentration of plant extracts were added into the $\mathrm{AgNO}_{3}$ solution. The color of solution changed from light faint to yellowish brown and colloidal brown at the end. This color change pattern indicates the formation of silver nanoparticles.

\section{UV Visible Spectroscopy}

To confirm the synthesis of nanoparticles UV visible spectroscopy was performed. The maximum absorbance band of silver nanoparticles was seen at $450 \mathrm{~nm}$ which indicate the green synthesis of silver nanoparticles.

\section{FTIR Spectroscopy}

The FTIR-spectrum of silver nanoparticles showed all major peaks of plant extract. The $\mathrm{OH}$-group peak was seen at $3385.04 \mathrm{~cm}^{-1}$ and $\mathrm{C}=\mathrm{O}$ group's peak was seen at $1660.09 \mathrm{~cm}^{-1}$. The $\mathrm{NH}$ group peak was observed at $1596.20 \mathrm{~cm}^{-1}$ (Figure 2).

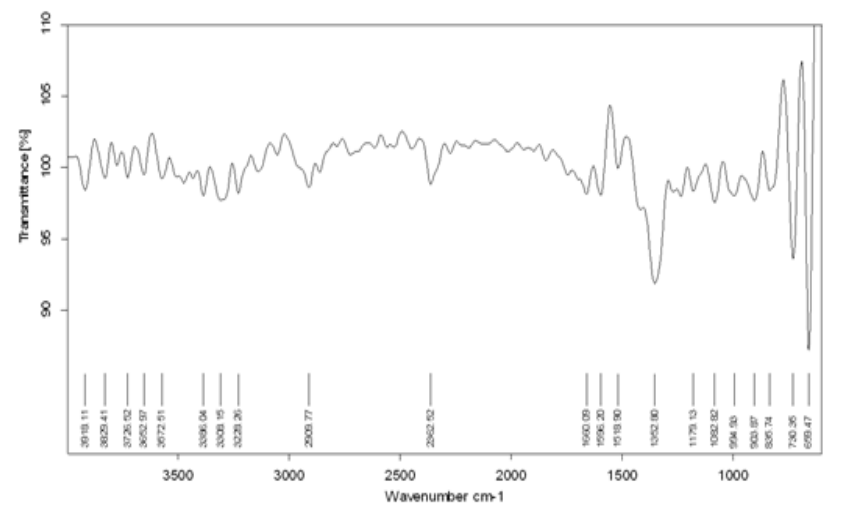

Figure 2. FTIR spectrum showing the different functional groups of silver nanoparticles.

\section{Particle Size and Zeta Potential}

The different formulation yields different sized silver nanoparticles. The optimum formulation was formulation 1 (Table 3) whose particle size was 92nm (Figure 3) and zeta potential was -24.8 mV (Figure 4).

Table 3. Average Particle Sizes of Different Formulations.

\begin{tabular}{|c|c|}
\hline Formulation & Average Particle Size (nm) \\
\hline 1 & 92 \\
\hline 2 & 98 \\
\hline 3 & 101 \\
\hline 4 & 105 \\
\hline 5 & 113 \\
\hline
\end{tabular}

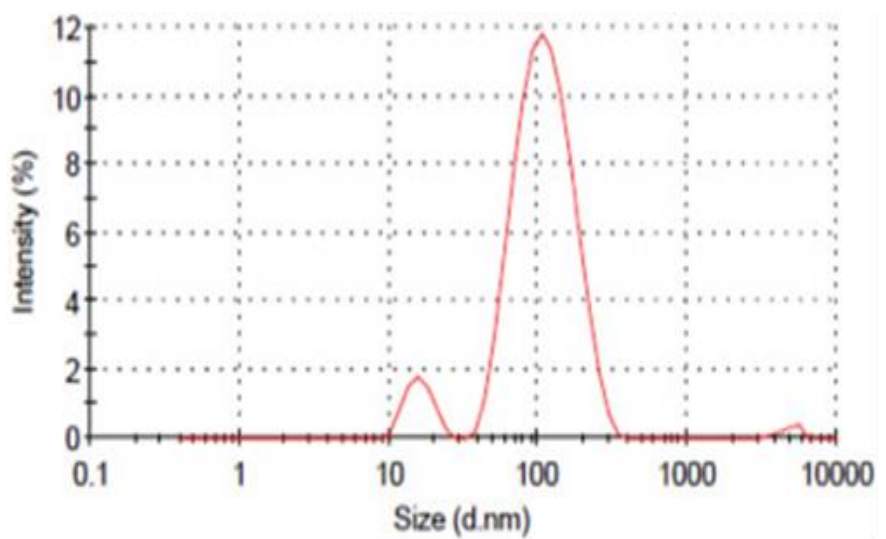

Figure 3. Graph showing variable particle sizes of silver nanoparticles of Crotalaria burhia.

Zeta Potential Distribution

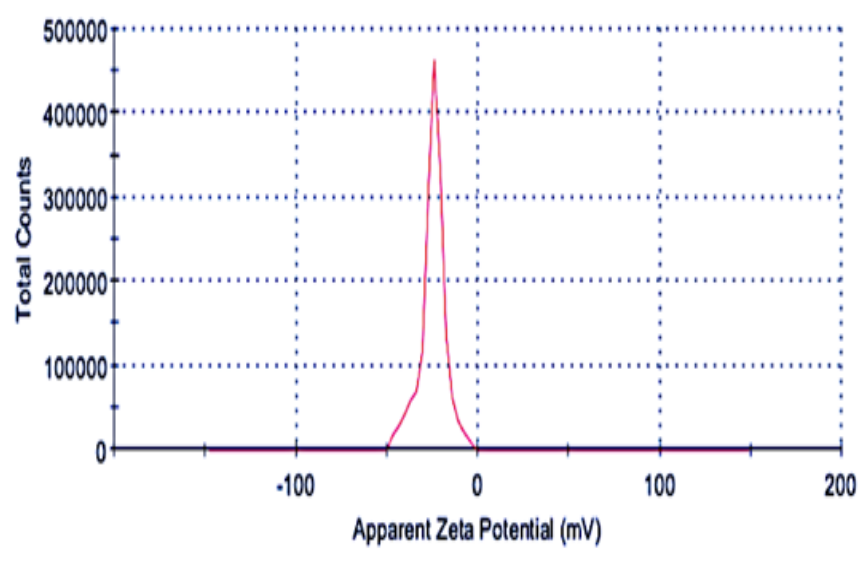

Figure 4. Graph indicating Zeta Potential distribution of silver nanoparticles.

\section{Scanning Electron Microscopy (SEM)}

The high-resolution SEM image of optimized formulation 1 was analyzed to study the outer shape of Ag NPs. The irregular, clumpy and some spherical type silver nanoparticles were observed in SEM image. Some particle seems big and some seems small in size (Figure 5).

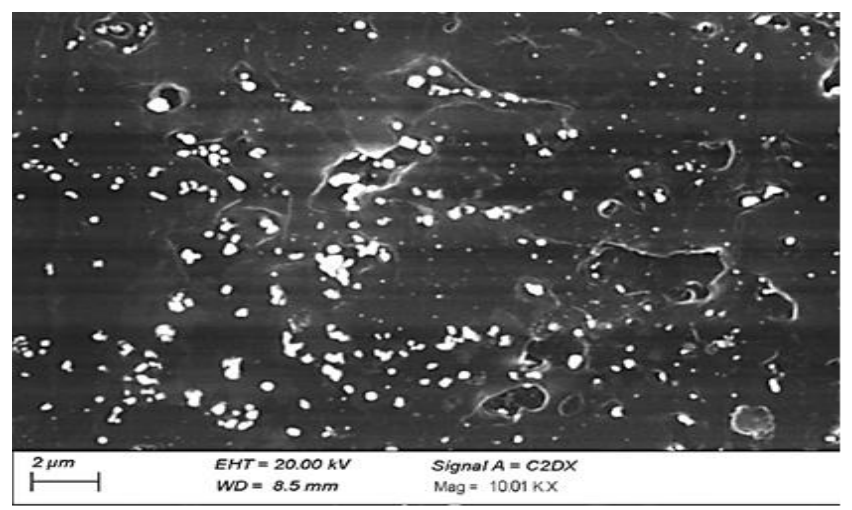

Figure 5. SEM image of variable sizes of silver nanoparticles of Crotalaria burhia. 


\section{Antioxidant Activity}

\section{Diphenyl-1-Picrylhydrazyl (DPPH) Method}

Antioxidant effect of Crotalaria burhia plant extract was measured by DPPH free radical scavenging assay method. Vitamin C (Ascorbic acid) was used as standard in this method. The results showed that it possess antioxidant potential (Table 4). The \%age inhibitory effect of Crotalaria burhia extract was $80.16 \pm 0.21$ while that of standard was $92.15 \pm 0.17$ (Figure 6).

Table 4. Scavenging Potential of Crotalaria burhia Plant Extract.

\begin{tabular}{|c|c|c|}
\hline \multicolumn{2}{|c|}{$\begin{array}{c}\text { Scavenging potential of Crotalaria burhia plant } \\
\text { extract }\end{array}$} \\
\hline $\begin{array}{c}\text { Concentration } \\
(\mathbf{m g} / \mathrm{ml})\end{array}$ & $\begin{array}{c}\text { Scavenging } \\
\text { potential }(\%)\end{array}$ & \multirow{2}{*}{ IC $_{50}(\mathbf{m g} / \mathbf{m l})$} \\
\hline 5.00 & 80.16 & \multirow{2}{*}{1} \\
\cline { 1 - 2 } 2.50 & 65.24 & \multirow{2}{*}{1.79} \\
\hline 1.25 & 40.23 & \\
\hline 0.75 & 25.33 & \\
\hline
\end{tabular}

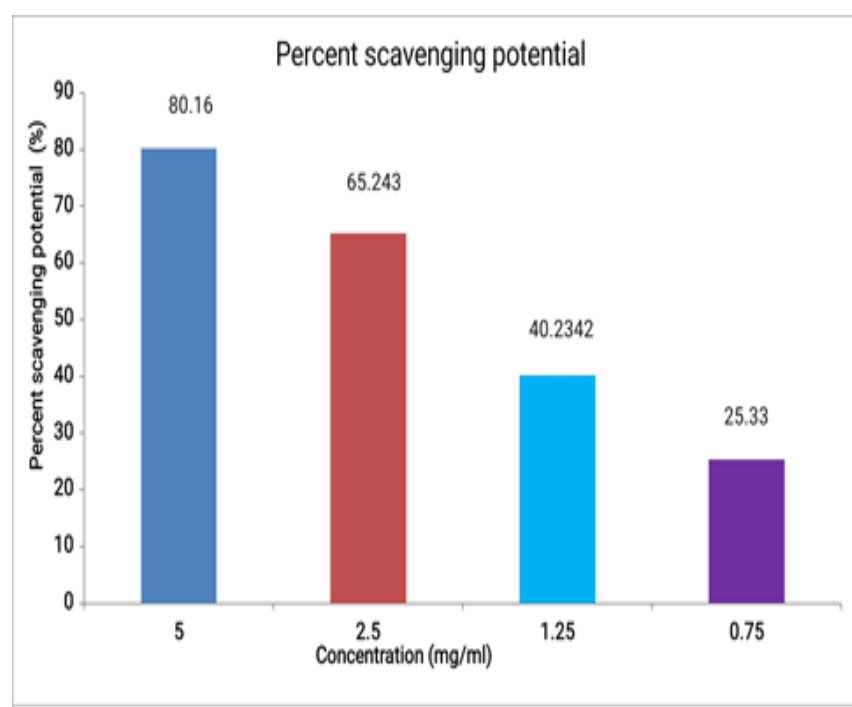

Figure 6. Percentage scavenging potential of Crotalaria burhia plant extract

\section{Antibacterial Activity}

The minimum inhibitory concentration of optimized formulation of standard was $2.1 \mathrm{mg} / \mathrm{ml}$ against $E$. coli and $2.4 \mathrm{mg} / \mathrm{ml}$ against $S$. aureus while the MIC value of silver nanoparticles was $2.5 \mathrm{mg} / \mathrm{ml}$ and $3.1 \mathrm{mg} / \mathrm{ml}$ against $E$. coli and $S$. aureus respectively (Table 5 ).

Table 5. MIC Values of Standard, Silver Nanoparticles, $\mathrm{AgNO}_{3}$ and Crotalaria burhia Plant Extract.

\begin{tabular}{|c|c|c|c|c|}
\hline \multirow{2}{*}{ Bacterial strain } & \multirow{2}{*}{$\begin{array}{c}\text { Standard } \\
\text { Ciprofloxacin } \\
\text { (mg/ml) }\end{array}$} & $\begin{array}{c}\text { Silver nanoparticles } \\
(\mathbf{m g} / \mathbf{m l})\end{array}$ & \multicolumn{2}{|c|}{ Control (mg/ml) } \\
\cline { 3 - 5 } & 2.1 & 2.5 & AgNO $_{3}$ & C. burhia extract \\
\hline E. coli & 2.4 & 3.1 & 4.3 & 6.9 \\
\hline S. aureus & & 5.4 & 7.2 \\
\hline
\end{tabular}

The MIC value of silver nanoparticles was a little bit higher than standard (Ciprofloxacin).

\section{DISCUSSION}

Crotalaria burhia is a medicinal plant which is rich in glycosides, flavonoid, alkaloid, antioxidants and carbohydrates. Previous studies reported that Crotalaria burhia have diverse pharmacological potential such as anticancer, analgesic, antiinflammatory anti-oxidant and anti-microbial activities [15]. The green synthesis of Ag NPs (silver nanoparticles) includes the use of bacteria, fungi, algae, yeast and/or plant extracts for the reduction of silver [16]. Silver nanoparticles have potent antibacterial activity [17]. The bactericidal activity of Ag NPs without causing toxicity to human cells, can make them a proper substitution for antibiotics [10].
The aim of this research study is the green synthesis and characterization of silver nanoparticles by using crude extract of Crotalaria burhia plant extract and to evaluate the antibacterial potential of silver nanoparticles. Abdel-Aziz and his collegues also confirmed the antioxidant and antibacterial activity of silver nano particles of Chenopodium morale leaf [18]. Antibcterial activity of silver Nano particles of many plants have been confirmed like Cestrum nocturnum [19], Rhazya stricta [20], Ferula gumosa, Ferula latisecta, Teucrium polium and Trachomitum venetum leaves and stems extract [21], Zea mays [22] and Malus domestica [23] etc.

In the 21st century, the use of small sized nanoparticles is a best approach for the delivery of active drug to cure different diseases, For this reason, 
the pharmacists, drug delivery scientists and researchers shift their focus on developing a novel drug delivery system for herbal medicines [6].

In our study different formulations of our plant extract yielded different sized silver nanoparticles. It all depends on the concentration of plant extract. High concentration of plant extract causes agglomeration of silver nanoparticles which cause big particles size [24]. The small size of silver nanoparticles increases the antibacterial potential of silver. The small size allows them to permeate into the bacterial membrane. The small sized silver nanoparticles have large surface to volume ratio area so they can interact with bacteria easily and can provide potent bactericidal activity [25]. Thus, in our study the optimum formulation of silver nanoparticles whose particle size was $92 \mathrm{~nm}$ and zeta potential was $-24.8 \mathrm{mV}$ showed high antibacterial activity against both bacteria $E$. coli and $S$. aureus. It was observed that MIC for $E$. coli was low as compared to $S$. aureus. As reported in previous studies, the AgNPs have no significant antibacterial activity against $\mathrm{S}$. aureus because it has thick peptidoglycan layer in its cell wall. This thick layer of peptidoglycan cause difficulty in absorption of silver nanoparticles into bacterial cytoplasms [17]. So, $E$. coli is less susceptible to $C$. burhia plant extract and its silver nanoparticles.

\section{CONCLUSION}

This study showed that these silver nanoparticles have potent antibacterial activity against $E$. coli and moderate antibacterial activity against $S$. aureus. Hence, it has been concluded that these nanoparticles can be used against multi drug resistant bacteria. In the future, the antitumor effect of these silver nanoparticles can be assessed by performing cytotoxic studies on different cancer cell lines.

\section{Conflict of interest}

The authors declare that there are no conflicts of interest.

\section{REFERENCES}

1. Venkataramaiah C. Chemical Constituents of Plants as Promising Drug Candidates: Nature's (God) Benefaction to Mankind. Chief Editor. 2020:53.

2. Mukeshwar P, Debnath M, Gupta S, Chikara SK. Phytomedicine: An ancient approach turning into future potential source of therapeutics. Journal of
Pharmacognosy and phytotherapy. 2011 Mar 31;3(2):27-37.

3. Iwu MW, Duncan AR, Okunji CO. New antimicrobials of plant origin. Perspectives on new crops and new uses. ASHS Press, Alexandria, VA. 1999:457-62.

4. Talaviya PA, Vyas BM, Sharma D, Indoria SP, Suman RK. Anti-inflammatory activity of four fractions of ethanolic extract of Crotalaria burhia Buch.-Ham. root in rats. National Journal of Physiology, Pharmacy and Pharmacology. 2014;4(3):213-7.

5. Devi VK, Jain N, Valli KS. Importance of novel drug delivery systems in herbal medicines. Pharmacognosy reviews. 2010 Jan;4(7):27.

6. Ansari SH, Islam F, Sameem M. Influence of nanotechnology on herbal drugs: A Review. Journal of advanced pharmaceutical technology \& research. 2012 Jul;3(3):142.

7. Zhang XF, Liu ZG, Shen W, Gurunathan S. Silver nanoparticles: synthesis, characterization, properties, applications, and therapeutic approaches. International journal of molecular sciences. 2016 Sep;17(9):1534.

8. Srikar SK, Giri DD, Pal DB, Mishra PK, Upadhyay SN. Green synthesis of silver nanoparticles: a review. Green and Sustainable Chemistry. 2016 Feb 16;6(1):34-56.

9. Servat-Medina L, González-Gómez A, ReyesOrtega F, Sousa IM, Queiroz ND, Zago PM, Jorge MP, Monteiro KM, de Carvalho JE, San Román J, Foglio MA. Chitosan-tripolyphosphate nanoparticles as Arrabidaea chica standardized extract carrier: synthesis, characterization, biocompatibility, and antiulcerogenic activity. International journal of nanomedicine. 2015;10:3897.

10. Rai MK, Deshmukh SD, Ingle AP, Gade AK. Silver nanoparticles: the powerful nanoweapon against multidrug-resistant bacteria. Journal of applied microbiology. 2012 May;112(5):841-52.

11. Firdhouse MJ, Lalitha $P$, Sripathi SK. Novel synthesis of silver nanoparticles using leaf ethanol extract of Pisonia grandis (R. Br). Der Pharma Chemica. 2012;4(6):2320-6.

12. Dayakar T, Rao KV, Bikshalu K, Rajendar V, Park $\mathrm{SH}$. Novel synthesis and structural analysis of zinc oxide nanoparticles for the non enzymatic glucose biosensor. Materials Science and Engineering: $\mathrm{C}$. 2017 Jun 1;75:1472-9.

13. Dela Peña AK, Camara JS. Antioxidant activity of talahib (Saccharum spontaneum) leaves ethanolic extract through DPPH assay. Philippine Journal of Natural and Social Sciences. 2019;1(1). 
14. de Aragao AP, de Oliveira TM, Quelemes PV, Perfeito ML, Araujo MC, Santiago JD, Cardoso VS, Quaresma P, de Almeida JR, da Silva DA. Green synthesis of silver nanoparticles using the seaweed Gracilaria birdiae and their antibacterial activity. Arabian Journal of Chemistry. 2019 Dec 1;12(8):4182-8.

15. Kataria S, Shrivastava B, Khajuria RK, Suri KA, Sharma P. Pharmacognostic evaluation of Crotalaria burhia buch.-Ham.

16. Guilger-Casagrande M, de Lima R. Synthesis of silver nanoparticles mediated by fungi: A Review. Frontiers in bioengineering and biotechnology. $2019 ; 7$.

17. Guzman M, Dille J, Godet S. Synthesis and antibacterial activity of silver nanoparticles against gram-positive and gram-negative bacteria. Nanomedicine: Nanotechnology, Biology and Medicine. 2012 Jan 1;8(1):37-45.

18. Abdel-Aziz MS, Shaheen MS, El-Nekeety AA, Abdel-Wahhab MA. Antioxidant and antibacterial activity of silver nanoparticles biosynthesized using Chenopodium murale leaf extract. Journal of Saudi Chemical Society. 2014 Sep 1;18(4):356-63.

19. Keshari AK, Srivastava R, Singh $P$, Yadav VB, Nath G. Antioxidant and antibacterial activity of silver nanoparticles synthesized by Cestrum nocturnum. Journal of Ayurveda and integrative medicine. 2020 Jan 1;11(1):37-44.

20. Shehzad A, Qureshi M, Jabeen S, Ahmad R, Alabdalall AH, Aljafary MA, Al-Suhaimi E. Synthesis, characterization and antibacterial activity of silver nanoparticles using Rhazya stricta. PeerJ. 2018 Dec 17;6:e6086.
21. Mohammadi F, Yousefi M, Ghahremanzadeh R. Green synthesis, characterization and antimicrobial activity of silver nanoparticles (AgNPs) using leaves and stems extract of some plants. Advanced Journal of Chemistry-Section A (Theoretical, Engineering and Applied Chemistry). 2019 Apr 1;2(4, pp. 266-385):266-75.

22. BARAN MF. Green synthesis, characterization and antimicrobial activity of silver nanoparticles (AgNPs) from maize (Zea mays L.).

23. Mariadoss AV, Ramachandran $\mathrm{V}$, Shalini $\mathrm{V}$, Agilan B, Franklin JH, Sanjay K, Alaa YG, Tawfiq MA, Ernest D. Green synthesis, characterization and antibacterial activity of silver nanoparticles by Malus domestica and its cytotoxic effect on (MCF7) cell line. Microbial pathogenesis. 2019 Oct 1;135:103609.

24. Yasmin S, Nouren $S$, Bhatti HN, Iqbal DN, Iftikhar S, Majeed J, Mustafa R, Nisar N, Nisar J, Nazir A, lqbal M. Green synthesis, characterization and photocatalytic applications of silver nanoparticles using Diospyros lotus. Green Processing and Synthesis. 2020 Jan 10;9(1):87-96.

25. He RX, Liang R, Peng P, Zhou YN. Effect of the size of silver nanoparticles on SERS signal enhancement. Journal of Nanoparticle Research. 2017 Aug 1;19(8):267.

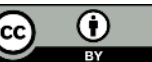

This is an Open Access article distributed under the terms of the Creative Commons Attribution License (http://creativecommons.org/licenses/by/4.0), which permits unrestricted use, distribution, and reproduction in any medium, provided the original work is properly cited. 